УДК 78.04(092)Ельгісер:784.4(=411.16)

Юлія Володимирівна Каплієнко-Ілюк, кандидат мистецтвознавства, доцент, доцент кафедри музики Чернівецького національного університету імені Ю. Федьковича (з 1.10.2017 докторант Одеської національної музичної академії ім. А. В. Нежданової) yuliyakaplienko@gmail.com

\title{
ВТІЛЕННЯ НАЦІОНАЛЬНОЇ ТЕМАТИКИ В ТВОРЧОСТІ ЙОСИПА ЕЛЬГІСЕРА
}

\begin{abstract}
Мета статті - характеристика творів єврейської тематики в фортепіанній та вокальній творчості одного з буковинських композиторів сучасності - Йосипа Ельгісера. Методологія. Застосовано методи історико-культурологічного, теоретичного та жканрово-стильового аналізу, що дозволило визначити особливості творів єврейської тематики в контексті дослідження музики композитора. Наукова новизна полягає у висвітленні єврейської тематики в музиці, аналізі творів Йосипа Ельгісера - буковинського композитора, творчий стиль якого малодосліджений у сучасному музикознавстві. Висновки. Творчість Йосипа Ельгісера надзвичайно оригінальна та самобутня. Більша частина його творчості - це фортепіанна музика, у різних жанрах якої розкрилися особливості його творчого стилю. Основна частина доробку Ельгісера програмна музика, яка тісно пов'язана з життям композитора. Особливо важливою темою його творчості стала трагічна доля єврейського народу. Створюючи музичні картини та портрети у вигляді фортепіанних мініатюр, Ельгісер поєднував їх в цикли під загальними програмними назвами.
\end{abstract}

Ключові слова: єврейська народна пісня, обробки єврейських пісень, єврейська фортепіанна музика, фортепіанний цикл, композитори Буковини, творчість Й. Ельгісера.

Kapliyenko-Iliuk Yulia Volodymyrivna, Ph.D. in History of Art, Associate Professor, Associate Professor of the Department of Music of Yu. Fedkovych Chernivtsi National University

\section{Embodiment of the national themes in the works of Joseph Elgiser}

The purpose of the article - is characteristics of works of the Jewish themes in piano and vocal creative works of one of the Bukovinian contemporary composers - Joseph Elgiser. Methodology. Methods of historic and culture, theoret$i c$, genre and style analysis have been applied. It permitted to determine peculiarities of works of the Jewish themes in the context of a research of composer's music. Scientific novelty lies in treatment of the Jewish themes in music, analysis of works of Joseph Elgiser - a Bukovinian composer, whose creative style has

(с) Каплієнко-Ілюк Ю. В., 2016 
been hardly investigated in the modern musicology. Conclusions. The works of Joseph Elgiser are extremely original and unique. A great part of his works is piano music in different genres, where peculiarities of his creative style are disclosed. The main part of the heritage of Elgiser is program music which is closely connected with the composer's life. Especially important theme of his works turned out to be a tragic destiny of the Jewish people. Creating music pictures and portraits in the form of piano miniatures, Elgiser connected them in cycles under common program headings.

Keywords: Jewish folk song, interpretation of the Jewish songs, Jewish piano music, piano cycle, composers of Bukovina, works of J. Elgiser.

Каплиенко-Илюк Юлия Владимировна, кандидат искусствоведения, доцент, доцент кафедры музыки Черновицкого национального университета им. Ю. Федьковича

Воплощение национальной тематики в творчестве Иосифа Эльгисера

Цель статьи - характеристика произведений еврейской тематики в фортепианном и вокальном творчестве одного из буковинских композиторов современности - Иосифа Эльгисера. Методология. Применены методы историко-культурологического, теоретического и жсанровостилевого анализа, что позволило определить особенности произведений еврейской тематики в контексте исследования музыки композитора. Научная новизна заключается в освещении еврейской тематики в музы$\kappa е$, анализе произведений Иосифа Эльгисера - буковинского композитоpa, творческий стиль которого малоисследован в современном музыковедении. Выводы. Творчество Иосифа Эльгисера чрезвычайно оригинальное и самобытное. Большая часть его творчества - это фортепианная музыка в разных жанрах, где раскрылись особенности его творческого стиля. Основная часть наследия Эльгисера - программная музыка, которая тесно связана с жизнью композитора. Особенно важной темой его творчества стала трагическая судьба еврейского народа. Создавая музыкальные картины и портреты в виде фортепианных миниатюр, Эльгисер объединял их в циклы под общими программными названиями.

Ключевые слова: еврейская народная песня, обработки еврейских песен, еврейская фортепианная музыка, фортепианный цикл, композиторы Буковины, творчество И. Эльгисера.

Актуальність теми дослідження. Серед буковинських композиторів XX - початку XXI століття особливе місце належить Йосипу Ельгісеру (1929-2014) - людині з великим талантом та надзвичайною долею. Піаніст, композитор, лікар-хірург, педагог, музикознавець, дослідник, громадський діяч, меценат Йосип Мойсейович Ельгісер прожив яскраве і водночас трагічне життя. Йому довелось пережити нелегке дитинство, бути в'язнем фашистського концтабору і завдяки 
музиці та художньому таланту вижити в ці страшні роки війни. Його музика достатньо різноманітна, багатожанрова, поєднує контрастну тематику, образність. У цілому, творчість Ельгісера програмна, її особлива ознака - автобіографічність. Дослідження діяльності митців, яскравих персоналій минулого та сьогодення - важливе завдання сучасного музикознавства. Тому будь-які розвідки у даному напрямку стануть актуальними в наш час.

Аналіз останніх досліджень і публікацій. Композиторська діяльність представників Буковини недостатньо досліджена. В існуючих підручниках з історії музики розглядаються питання розвитку музичної культури Буковини в контексті загальної характеристики західноукраїнської музики. Проте окремого дослідження культури краю, особливо його сучасних митців, немає у музикознавчій літературі. У сучасному науковому просторі $є$ декілька публікацій, присвячених історичному минулому мистецтва Буковини, серед яких дві праці історично-публіцистичного характеру К. Демочко [1; 2]. Більш детальним та інформативним джерелом про історію музичної культури й освіти Буковини залишається колективна праця науковців кафедри музики Чернівецького національного університету імені Ю. Федьковича [7]. Однак у цих розвідках стиль композиторів Буковини не досліджується. Творчість Й. Ельгісера не аналізується у мистецтвознавчій літературі. Про його життя, виконавську та громадську діяльність існує багато публікацій у періодичній пресі та довідкових виданнях. У 2007 році вийшла у світ єдина книга А. Ісака «Лицар музики» [5], де увага приділяється біографії Ельгісера, проте публіцистичний характер видання не дає змогу вважати іiі грунтовним дослідженням творчості композитора. Цього ж року була захищена дипломна робота I. Кобяцької, в якій аналізуються фортепіанні цикли Й. Ельгісера [6].

Мета дослідження - характеристика творів єврейської тематики в фортепіанній та вокальній творчості Йосипа Ельгісера.

Основний виклад матеріалу. Особливо важливою та надзвичайно болісною темою творчості Йосипа Ельгісера була трагічна доля єврейського народу в роки Другої світової війни, адже йому самому довелось пережити тортури німецького гетто. Невільницькі пісні, почуті тоді в полоні, вже майже через п'ятдесят років Ельгісер покладе в основу збірки «Сврейська фортепіанна музика: обробки єврейських народних пісень». У збірник увійшли твори єврейської тематики, написані для фортепіано, обробки народних пісень. Єврейські народні пісні, що були записані Ельгісером від Хани Ярмолинської, Елі Бен- 
дионовича та Рози Штейнберг з Чернівців та увійшли до збірки, цілком оригінальні твори, яких навіть немає в «Антології єврейської народної пісні» [3]. Традиції збирання єврейського музичного фольклору ведуть ще до кінця ХІХ століття, коли студент Московської консерваторії Енгель збирав, записуючи на фонограф, та досліджував єврейську народну музику. Пізніше М. Римський-Корсаков заохочував єврейських студентів Петербурзької консерваторії до вивчення ïх народної пісенності та спонукав спиратися на неї як на основу їх оригінальної національної творчості. Він сам проявляв інтерес до єврейської музики, вбачаючи в ній релікт стародавнього східного мелосу. Як зазначається в одному з досліджень історії єврейського народу, «Для своїх учнів-євреїв видатний російський композитор виступав у ролі, подібній тій, яку грав Стасов в середовищі єврейських художників» $[4,503]$. У XX столітті ці традиції були підхоплені іншими композиторами, зокрема Д. Шостаковичем, який видав цикл пісень «3 єврейської народної поезії».

Особливе місце серед творів видання Й. Ельгісера, присвяченого єврейському народу, займає «Еврейська сюїта», яка була написана автором після відвідування хотинської єврейської общини, де Й. Ельгісер зустрівся з людьми, які так само, як і він, пройшли через гітлерівську неволю. Перша частина сюїти «У Хотинській общині» розкриває гірку сповідь колишніх бранців, їх почуття і страждання. Увесь трагізм ситуації сконцентровано у розвитку мелодичної лінії, яка повільно, важко, поступово піднімається, робить спроби досягнення певної вершини, що можна порівняти з нелюдськими зусиллями багатостраждального народу, який намагається встати з колін. Жорсткі акорди початкової побудови, з різкими секундовими нашаруваннями всередині співзвуч та секундовими висхідними зрушеннями цих вертикальних комплексів, надзвичайно точно зображають жахливу машину смерті, заведену фашистським режимом. Висхідні малосекундові інтонації, із загостреними хроматизмами, та нестримний, хоча важкий і повільний, майже непомітний рух угору так чи інакше символізують риторичне прагнення до світла, добра, надії і перемоги. Середній розділ складної тричастинної форми створює певний контраст при незмінній соль-мінорній тональності. Пожвавлення темпу додає ще більшого хвилювання. Нарочите синхронне підкреслення усіма голосами фактури карбованого ритму, що повторюється впродовж першого періоду цього розділу, створює враження наступу руйнівної сили, яку неможливо подолати. Результатом стає наступна 
побудова, де ритмічні синкопи у поєднанні з жорсткими вертикалями змальовують картину жорстоких катувань. Завершує форму коротка побудова, яку лише за ознакою темпу можна розцінювати як репризу. Проте тут надзвичайно переконливо передається біль і страждання народу: «кульгавий» ритм у вигляді зворотного пунктиру, повільний рух хроматизмами, що, як болісне відлуння, почергово імітується і нарешті призупиняється.

Наступна, друга частина сюїти - «Фрейлехс» - жанрова сценка народного свята. Ця частина циклу - лірично-танцювальне відсторонення, контраст між дійсністю, реальністю та сутністю єврейського народу з його культурою, традиціями, піснями і танцями. Фрейлехс - це найбільш відомий колективний єврейський танець, який виконують на весіллях. Танцюючи фрейлехс, люди шикуються в одну лінію або в коло та рухаються під музику з конкретним набором рухів та своєрідною ходою; коло може рухатись вліво або вправо. Цей танець має ще такі назви, як «карагод», «рейдл» і навіть «сім-сорок». Основний танцювальний характер п’єси «Фрейлехс» Ельгісера відчувається не одразу, а лише завдяки характерному тактовому розміру (регулярно-перемінний $2 / 4+3 / 4,4 / 4+2 / 4$ ) упізнаються ознаки жанру. На перший план виходить сумовита й досить лірична початкова інтонація кружляння в соль мінорі, що по черзі переходить з голосу в голос та розвивається на фоні мірно витриманих басів. Ця тема проходить кілька разів у формі, надаючи структурі твору рис рондальності. Середина першого розділу проявляє тісний зв'язок з першою частиною циклу, де використані подібні гострі акордові вертикалі 3 малими секундами у їх складі. Це своєрідна лейтінтонація, яка проходить крізь увесь сюїтний цикл то у вигляді вертикальних споруд, то у вигляді мелодичного «болісного» руху. Окрім того, наявність синкоп теж тісно пов’язує цей розділ з першою частиною циклу. Середній розділ II частини більш рухливого характеру, незважаючи на утримання мінорного ладу (до мінор), барви якого надають стриманості. Гучна динаміка, нестримний рух, пожвавлення темпу додають цьому розділу кульмінаційності, створюючи враження загальної танцювальної ейфорії. Проте з появою теми кружляння з першого розділу все повертається до початкового хвилюючого настрою, нагадуючи про невідворотність долі.

Лірично-схвильована танцювальна частина циклу змінюється драматичною «Ремінісценцією про табірне минуле». Третя частина циклу, його кульмінація, виникає як драматично схвильована та на- 
пружена розповідь, в якій сповна проявилися гіркота, скорбота та страждання. Для втілення свого задуму композитор обрав форму варіацій, де у двох основних розділах форми поєдналися ознаки подвійних варіацій, варіацій на basso ostinato та soprano ostinato. На відмінну від попередніх двох частин, які були написані в одній тональності, в третій частині циклу композитор змінює основний тональний центр. Тема, що покладена в основу варіацій, спочатку викладена одноголосно, в низькому регістрі, стримано, напружено і трагічно. Мелодична лінія теми побудована на безперервному диханні та охоплює вісім тактів. Ладовою основою теми стає фрігійський ля мінор, збагачений хроматичними звуками. Низхідний загальний рух мелодії окреслює ознаки прихованого двоголосся, де лінія нижнього шару яскраво вимальовує низхідний жорсткий хід по хроматизмах. Такий символічний низхідний рух, що відповідає риторичній фігурі passus duriusculus, був досить розповсюджений в період розквіту варіацій на basso ostinato (XVI-XVIII ст.) поряд із перевагою низхідного руху (katabasis) та означав сходження, падіння, смерть. Одразу пригадуються аналогічні теми в західноєвропейській музиці, зокрема теми фуг з ДТК та Crucifixsus з Високої меси Й. С. Баха. Отже, тема вже з самого початкового викладу створює безперервний потік виразних інтонацій, котрі нагадують стогін жорстоко закатованих, страждаючих людей. За темою слідують п'ять варіацій, де на фоні незмінного басу варіюється іiї контрапунктичний супровід. Композитор застосовує різні варіанти ритмічного перетворення верхніх голосів та часткові видозміни гармонічного розвитку. Остання, п'ята варіація з розділу варіацій на basso ostinato створює найбільше напруження, виконуючи функцію кульмінації. Змінюючи фактуру до ущільненого акордового викладу з новими для твору артикуляційними прийомами та октавним дублюванням теми, досягається відчуття найбільшої напруги та драматизму. Кінець побудови, що утворює період розімкненого типу, стає логічною зв'язкою до наступного розділу форми - варіацій на soprano ostinato.

В якості тематизму цього розділу Ельгісер обирає інверсію теми варіацій на basso ostinato, даючи тему в дзеркальному оберненні. Вона змішується у більш високий регістр, а при варіюванні зрушується октавою вище. В даному типі варіацій тема знову ж таки звучить остинатно, а видозмінюється акомпанемент до неї. Перша варіація побудована на відносно контрастному двоголоссі, де контрапунктом до теми стає протискладення, яке своїми графічними контура- 
ми нагадує перший варіант теми. Таке «неповноголосся» у вигляді двоголосного проведення, як засіб розвитку першої варіації, надає поштовх до наступних перетворень, до поступового накопичення фактурних голосів та викладу останньої варіації, що виконує функцію коди. Заключна варіація підготовлена тритактовою зв'язкою імпровізаційного характеру та повертає варіант теми на basso ostinato. Грандіозне звучання підкреслюється щільним акордовим викладом з басовим форшлагом, де на перший план виходять контури теми, яка звучить одночасно в чотирьох октавах. Така повнота звучання ще раз підкреслює значимість тематичного матеріалу та створює враження хоралу-реквієму по загиблих, страчених і замучених неволею євреїв на фоні поминального дзвону. Такий прийом фактурного викладу нагадує подібні моменти в творчості М. Мусоргського, а тема дзвонів споріднює цей епізод з фортепіанною звукозображальністю С. Рахманінова.

Четверта частина циклу - «Вічний блукач» сприймається як справжній симфонічний фінал після похмурої, траурної третьої частини. Основна тема фіналу - «тема блукача», яку можна сприймати як узагальнений образ вічно мандруючого єврейського народу, використана тут як рефрен п'ятичастинного рондо. Мелодія рефрену монотонного характеру супроводжується нестійкими та альтерованими акордами соль-дієз мінору. В першому проведенні тема розростається до простої тричастинної форми з динамічною репризою. Плавна енгармонічна модуляція переводить до ля мінору першого епізоду рондо, який занурює у світ романтичної лірики. На фоні ноктюрнової фактури акомпанементу звучить витончена та візерунчаста мелодія 3 характерним національним колоритом. Друга поява рефрену скорочена, тематичний матеріал видозмінений, мелодія «блукача» розірвана між двома октавами, що вносить характерний неспокій. Наступний епізод відносно повільний, пригнічений завдяки сі-бемоль мінору, який нерідко пов'язується з трагічними образами та ситуаціями. Розвиток нагадує схвильовану розповідь, яка поступово досягає апогею. Завершує форму основна тема рондо, що звучить тут досить динамічно завдяки щільному акордовому викладу та майже синхронному ритму усіх голосів фактури. Отже, фінал сюїти демонструє приреченість ситуації, пов’язаної з долею всіх євреїв, котрі змушені блукати світом. У цілому сюїта достатньо логічно побудована, спирається на чотиричастинну структуру, де кожна з частин має свій програмний задум, може претендувати на самостійність, що є ознакою жанру, і в той же 
час твір надзвичайно цілісний, де можливо знайти й риси сонатносимфонічного циклу та принципу симфонічного розвитку.

Центральною темою збірки «Сврейська фортепіанна музика: обробки єврейських народних пісень» $є$ тема Голокосту, що проходить, як згадує А. Ісак, «червоною ниткою» крізь ще один фортепіанний цикл - «Ремінісценція про туристичну поїздку до Німеччини». «В усіх трьох іiї частинах — «B Трептов-парку», «Пам'ятайте, в'язні Закзенгаузена, дорогу смерті», «Прощальна вечеря у підвалі Ауербаха» - звучить туга за шістьма мільйонами євреїв, які безвинно загинули в роки Другої світової війни» $[5,93]$.

Перша частина сюїти «В Трептов-парку» розпочинається з величного та стриманого маршу-ходи, що символізує крокування парком, де розташований меморіал, присвячений Другій світовій війні, пам'ятник радянському солдату та поховання близько 7 тисяч солдат. Пригнічений настрій та болісне переживання, закладені в цій п'єсі, підсилюються мінорною тональністю, акордовим складом фактури, мірними тривалостями та пунктирним ритмом. Усі ці ознаки сприяють враженню звучання поховального маршу. Характерні жорсткі співзвуччя, додані тони в акордах з перевагою секундових нашарувань, октавні дублювання у низькому регістрі в той же час відтворюють образ гранітного пам'ятника в центрі меморіалу та непохитної пам'яті про жертви війни.

Складна тричастинна форма, покладена в основу цієї частини циклу, достатньо контрастно розкриває усі переживання скорботної подорожі. Урочиста й пригнічена маршова хода по Трептов-парку змінюється надзвичайно експресивною та схвильованою середньою частиною, яка утворюється з двох контрастних періодів у мі-бемоль мінорі та до мажорі. Перший розділ середини побудовано на остинатному тріольному ритмі в середньому шарі фактури на фоні тонічного органного пункту, створюючи враження безперервного гіркого плачу. Як голос минулого, своєрідний скорботний хорал, з'являється партія правої руки, поєднуючи минуле і сучасне в єдиному траурному звучанні. Увесь розвиток поступово сходить до низького регістру, готуючи нові спогади, які надзвичайно яскраво представлені в другому періоді простої двочастинної форми. Тут композитор вдається до звукозображальності, де пунктирний ритм, підкреслений октавним подвоєнням звуків у низькому регістрі, передає стукіт копит коня. Батальна сцена розкрита дуже реалістично, де композитор музичними засобами створює й моменти боротьби, й звук автоматних черг. 
Основний тональний центр майже зовсім не відчутний, адже сповнений усіма звуками хроматичної системи. Динамічна реприза форми синтезувала ознаки траурного маршу та скорботного епізоду, залучаючи тріольний підголосок плачу з середини в загальну акордову фактуру репризи. Проте в заключному розділі він, як безупинний біль, кружляє в низькому регістрі з октавним подвоєнням. Завершують частину мірні, монолітні акорди, символізуючи безвихідь і смерть.

Цей гнітючий настрій набуває продовження в наступній частині циклу «Пам'ятайте, в'язні Закзенгаузена, дорогу смерті», де в лаконічній простій тричастинній формі розкрито увесь біль і страждання людей, які йшли «Дорогою смерті». Жорсткі квартакорди на $s f$ розпочинають п’єсу, і на їх фоні у низькому регістрі звучить бездушна і механічна тема. Епізоди на piano не знімають напруження, адже дисонуючі співзвуччя, повторення окремих інтонаційних зворотів, ритмічні остинатні фігури створюють враження безперервного благання, мольби. Реприза форми стає кульмінацією всього ворожого, жахливого та бездушного.

Остання частина сюїти «Прощальна вечеря у підвалі Ауербаха» стилістично відрізняється від усього попереднього матеріалу. П'єса дещо романтичного настрою з елементами танцювальності, де усі складові музичної мови позбавлені жорсткості. Створений образ, легкий, безтурботний настрій, котрий домінує протягом цієї частини, позитивно завершує весь цикл. Отже, «Ремінісценція про туристичну поїздку до Німеччини» відтворює враження композитора від подорожі у Німеччину, де тісно переплелися переживання і спогади про трагічну долю єврейського народу, його минуле, жахливі роки війни та позитивний настрій від завершення подорожі вечерею у відомому лейпцігському ресторані. Даний контраст образів, переживань підкреслено композитором і протиставленням різних типів організації музичної тканини, стилю: минуле висвітлено засобами контрастного поліфонічного мислення, сучасне - гомофонно-гармонічним стилем.

Переживання і почуття, пов'язнані з трагедією Другої світової війни, Й. Ельгісер передав у п’єсі «Бабин Яр», де в якості епіграфа обрав слова Є. Євтушенка: «Над Бабьим Яром памятников нет / Крутой обрыв, как грубое надгробье». Відповіддю на ці слова стала музична п’єса Ельгісера та поетичні рядки автора: «О Бабьем Яре памятники есть / На всей земле не перечесть, / Обозначен след фашистов своры / Еврейской кровью белизна Меноры. / Слезой застывшей меркнет воск / Потомки помнят Холокост. / Рядами предков путь очертан / 
От Куриневки призрак смерти, / Собачий лай и зверств кошмар: / Так обозначен Бабий Яр» $[8,41]$. Знову у творі Ельгісера постають образи фашизму, які він нерідко зображає засобами акордового складу з перевагою квартових акордів, жорстких співзвуч. Акценти слабких або відносно сильних долів такту, нерівномірність ритмічної пульсації створюють враження неочікуваних ударів, нерівномірного пульсу та вбивчих пострілів. Тематика твору та використаний епіграф Є. Євтушенка пов'язує задум композитора з ідеєю Д. Шостаковича в його 13-й симфонії, де події Бабиного Яру стали основою I частини. Цей твір Й. Ельгісер виконував у Києві на відзначенні 65-ї річниці трагічних подій у Бабиному Яру.

Поряд з фортепіанними творами, присвяченими єврейській тематиці, композитор займався й обробками єврейських народних пісень. Вони мають різну тематику та образний зміст. Ельгісер звертався до пісень, де розкривається важка доля єврейського народу, любовна лірика, побутова тематика: «Заповіт Мангера», «В хедере», «Давай помиримось», «Весільна сукня», «Нічні пісні», «Коло містечка стоїть хата», «Мученицька пісня» тощо. Народні пісні, покладені в основу композицій Ельгісера, записані у різні роки з вуст представників єврейської общини (1991, 2001 рр.) та місії з Канади на святі «Пейсах» (1996 р.). Залежно від характеру та змісту пісні музичні особливості твору змінювали свої характеристики та збагачувались відповідними засобами. Мелодії єврейських пісень насичені м'якими ліричними інтонаціями з характерними ходами на збільшені секунди, що вплинуло на їх ладову організацію, в основі якої нерідко покладено двічі гармонічний мінор. Проте більшість пісень діатонічні. В твори драматичного змісту залучається речитація з роздрібненими долями групою повторюваних нот. Експресивній манері вокального виконання сприяє й партія фортепіано, що увібрала в себе ознаки єврейської музики.

Висновки. Отже, серед творів різноманітного змісту значне місце у творчому доробку Ельгісера займає музика єврейської тематики. Зібрані власними зусиллями народні пісні та пригадані невільницькі солоспіви воєнних часів композитор покладає в основу фортепіанних сюїтних циклів та вокальних творів з фортепіанним супроводом. Підкреслюючи важливість цієї теми, Ельгісер надзвичайно чутливо поставився до втілення задуму. У цих творах виявляються найяскравіші риси творчості митця, де академічні прийоми композиторської техніки поєднані з власним мелодико-гармонічним стилем та особливостями єврейської народної музики. 


\section{СПИСОК ЛІТЕРАТУРИ}

1. Демочко К. Мистецька Буковина: нариси з минулого. Чернівці: Книги XXI, 2008. $336 \mathrm{c}$.

2. Демочко К. Музична Буковина: сторінки історії. Київ: Музична Украіна, 1990. 136 с.

3. Еврейская народная песня: антология / сост. М. Д. Гольдин. Москва: Композитор, 1994. 448 с.

4. История еврейского народа в России / под ред. И. Лерье. Москва: Мосты культуры, 2012. Т. 2: От разделов Польши до падения Российской империи. $534 \mathrm{c.}$

5. Ісак А. Лицар музики: Штрихи до портрета заслуженого діяча мистецтв України, володаря Золотої медалі ЮНЕСКО та звання «Золоте ім’я світової культури» Йосипа Мойсейовича Ельгісера. Чернівці: Зелена Буковина, 2007. 134 с.

6. Кобяцкая И. Фортепианный цикл в творчестве Иосифа Ельгисера: дипломная работа. Одесса, 2007. 143 с.

7. Кушніренко А., Залуцький О., Вишпінська Я. Історія музичної культури й освіти Буковини: навч. посібник. Чернівці: Чернівецький нац. ун-т, 2011. $376 \mathrm{c}$.

8. Эльгисер И. Еврейская фортепианная музыка. Обработки еврейских народних песен: нотное издание. Черновцы: Золоті литаври, 2004. 86 с.

\section{REFERENCES}

1. Demochko K. (2008). Art Bukovina: essays from the past. Chernivtsi: Knigi XXI [in Ukrainian].

2. Demochko K. (1990). Musical Bukovina: history pages. Kyiv: Muzichna Ukraina [in Ukrainian].

3. Goldin M. D. (Eds). (1994). Jewish folk song: anthology. Moscow: Kompozitor [in Russian].

4. Lere I. (Eds). (2012). History of the Jewish people in Russia (Vol.2). Moscow: Mosty kultury [in Russian].

5. Isak A. (2007). Knight of music: Strokes to the portrait of the Honored Art Worker of Ukraine, the holder of the UNESCO Gold Medal and the title «The Golden Name of World Culture» by Joseph Elgiser. Chernivtsi: Zelena Bukovina [in Ukrainian].

6. Kobyatskaya I. (2007). Piano cycle in the works of Joseph Elgiser. Graduate work. Odessa [in Ukrainian].

7. Kushnirenko A. M., Zalutskiy O. V., Vishpinska Ya.M. (2011). History of musical culture and education of Bukovina. Chernivtsi: Chernivetskiy nats. un-t [in Ukrainian].

8. Elgiser Y. (2004). Jewish piano music. Processing of Jewish folk songs. Chernovtsy: Zoloti litavri [in Ukrainian].

Стаття надійшла до редакції 14.06.2016 